\title{
Microbial assessment and effect of seasonal change on the removal efficiency of FAB based sewage treatment plant
}

\author{
Dilafroza Wani*, Ashok K. Pandit and Azra N Kamili \\ *Correspondence: dilafroza.wani@gmail.com \\ Centre of Research for Development, University of Kashmir, Srinagar-190006 Jammu and Kashmir, India.
}

\begin{abstract}
Background: Wastewater treatment is aimed at removing impurities present in wastewater in the form of floating material, suspended solids, biodegradable organics and elimination of pathogens., but there needs to be regular monitoring to see working capability and overall efficiency.

Methods: Microbiological examination of samples was conducted as promptly as possible (within 24 hours) after collection or were stored at $4^{\circ} \mathrm{C}$ in a refrigerator until use. A multiple tube fermentation technique or Most Probable Number (MPN) technique (APHA, 1998) was used to determine bacterial indicators as Total Coliforms (TC), Faecal Coliforms (FC) and Faecal Streptococci (FS) according to standard methods as described in APHA (1998). Student t-test and Chi-square tests were used to compare the data.

Conclusions: In order to assess the microbial evaluation and effect of season on Hazratbal sewage treatment plant, a study was carried out during 2010-2011. The results showed significant $(\mathrm{p}<0.05)$ differences in total coliform between wastewater (raw) and treated wastewater (final) from the sewage treatment plant. The comparison of percentage efficiency rate of the treatment plant showed significant differences among different microbial parameters. Removal efficiency rate was greater in Faecal Coliform (72.33\%) and least for Faecal Streptococci (38.70\%). The results showed significant variation among different seasons $(\mathrm{p}<0.05)$. It seems from the data that season play an important role in predicting the efficiency of this sewage treatment plant. The greater efficiency rate was observed in summer and autumn months and least in winters. Finally it was concluded that although Hazratbal sewage treatment plant succeeded in removing some pathogens from the influents, but it is little less than the required and efficiency rate did not reach to the level of national and international standards and as such discharge of effluent from this sewage treatment plant into the lake is not suitable.
\end{abstract}

Keywords: Microbial evaluation; faecal coliform; faecal streptococci; total coliforms

\section{Introduction}

Wastewater disposal is done both on land and in water body by most urban centres without pretreatment. Wastewater collection in most urban centres is done by means of sewerage system which is carried to the treatment plants and finally disposed off into the environment. Wastewater treatment must be made mandatory for all sizes of urban centres [1]. Wastewater treatment is aimed at removing impurities present in wastewater in the form of floating material, suspended solids, biodegradable organics and elimination of pathogens. The two fundamental reasons for treating wastewater is the prevention of pollution of water sources and protection of public health by safeguarding water supplies against the spread of diseases [2].

Microbial pollutants can also serve as indicators of water quality. For instance total and faecal coliforms, and the entercocci - faecal streptococci are the indicator organisms currently used in the public health arena as they indicate fecal contamination [3] and presence of enteric pathogens in surrounding water [4]. Indicator organisms are always used to determine the relative risk of the possible presence of a particular pathogen in wastewater [5]. Coliform bacteria include all aerobic and facultative anaerobic, gram-negative, nonsporeforming, rod-shaped bacteria that ferment lactose with gas formation, and comprises mainly species of the genera Citrobacter, Enterobacter and Klebsiella and also includes Faecal coliforms, of which Escherichia coli is the predominant species [6] and Faecal streptococci. These are found naturally in the soil, as well as in faeces. Usually between $60 \%$ and $90 \%$ of total coliforms are faecal coliforms. E. coli are a particular species of bacteria that may or may not be pathogenic but are ubiquitous in the human intestinal tract. Faecal streptococci is an indicator in tropical conditions and especially used to compare the survival with that of Salmonellae.

The increased population and urbanization in Srinagar city has resulted in an increase in the discharge of domestic sewage into the water bodies especially Dal lake, due to which the lake has undergone tremendous changes in its chemical, biological and trophic status. So there is an immediate need for trapping these pollutants before releasing into the lake. It was in this background that wastewater treatment plant was installed at the periphree 
of the Dal lake at Hazratbal to treat the wastewater coming from Hazratbal area and University campus. In past, no extensive study has been carried out to assess the efficiency and quality of these STPs. Because of the associated dangers of sewage, present study was carried out to investigate the impact of the wastewater effluent discharged and to estimate the removal efficiency of STPs around the Dal lake. In addition, seasonal change in the removal efficiency rate was evaluated.

\section{Material and methods \\ Study area}

The study was conducted on Hazratbal Sewage Treatment

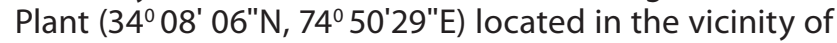
Dal lake with a design capacity of 7.5 MLD. The wastewater treatment plant receives domestic sewage from the Hazratbal area of Srinagar city and treat it using the FAB based biological treatment systems. The final treated effluent of Hazratbal sewage treatment plant is discharged into the Dal lake.

The water samples were collected at the inlet and outlet of sewage treatment plant on seasonal basis for a period of 12 months, in white plastic containers, which were previously sterilized with $70 \%$ alcohol and rinsed with distilled water. At the sites, the containers were rinsed thrice with the wastewater before being used to collect the samples.

Microbiological examination of samples was conducted as promptly as possible (within 24 hours) after collection or were stored at $4^{\circ} \mathrm{C}$ in a refrigerator until use. A multiple tube fermentation technique or Most Probable Number (MPN) technique [7] was used to determine bacterial indicators as Total Coliforms (TC), Faecal Coliforms (FC) and Faecal Streptococci (FS) according to standard methods as described in APHA [7]. Multiple tube fermentation method used in present work included measurement of total plate count and MPN of coliform. After incubation for 24 hours at $35^{\circ} \mathrm{C}$ results were recorded when acid and gas liberated in durham tubes with change of colour to yellow. Lactose broth was used as a medium for the growth of coliform. Number of positive test tubes with acid (yellow colouration) and gas production were matched with the McCardy's Statistical Table and the most probable number (MPN) of coliforms present in $100 \mathrm{ml}$ of each sample was thus determined. Different pathogenic bacteria were enumerated by serial dilution method. $0.1 \mathrm{ml}$ aliquots of each dilution $\left(10^{-1}\right.$ to $\left.10^{-7}\right)$ directly from tubes was inoculated in triplicate on FC agar, Mac Conkey agar and FS agar by spread-plate method for enumeration of Faecal coliform, $E$. coli and Faecal streptococci respectively. The culture plates were incubated at $37^{\circ} \mathrm{C}$ for $24 \mathrm{~h}$. The removal efficiency of bacterial indicators was calculated using the following formula $[8,9]$.

Removal efficiency $=\frac{\text { MPN/100ml in influent }-M P N / 100 \mathrm{ml} \text { in effluent }}{M P N / 100 \mathrm{ml} \text { in influent }} \times 100$

\section{Results}

The results showed significant differences $(p<0.05)$ in mean values of microbial load (Faecal coliform, E. coli and

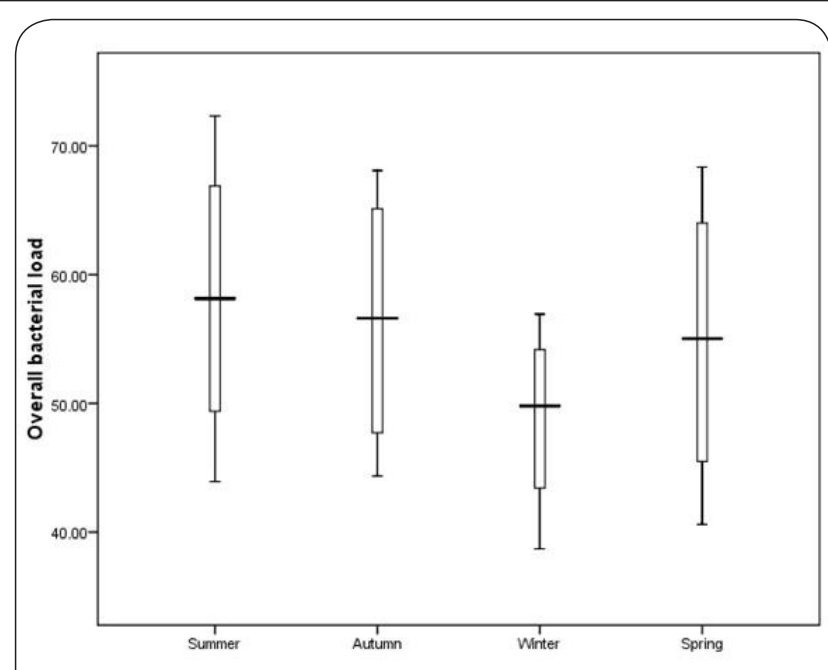

Figure 1. Seasonal variation of bacterial load in Hazratbal STP.

Table 1. Comparison of average raw and effluent microbial load $( \pm S D)$ in hazratbal sewage treatment plant with statistical analysis.

\begin{tabular}{llllll}
\hline Parameter & Raw & Effluent & t-test & df & p-value \\
\hline Total coliform & $8.78 \pm 0.13$ & $7.62 \pm 0.10$ & 13.6 & 6 & $\mathrm{p}<0.05$ \\
Faecal coliform & $7.83 \pm 0.07$ & $6.78 \pm 0.06$ & 14.5 & 6 & $\mathrm{p}<0.05$ \\
E. coli & $7.63 \pm 0.14$ & $6.82 \pm 0.03$ & 15.2 & 6 & $\mathrm{p}<0.05$ \\
Faecal streptococci & $6.85 \pm 0.11$ & $6.08 \pm 0.05$ & 12.8 & 6 & $\mathrm{p}<0.05$ \\
\hline
\end{tabular}

Faecal streptococci) between wastewater (raw) and treated wastewater (final) from the from sewage treatment plant. The total coliform was significantly lower $(t$-test=13.6, $p<0.05)$ in effluent $(7.62 \pm 0.10 \mathrm{MPN} / 100 \mathrm{~mL})$ in comparison to raw (8.78 $\pm 0.13 \mathrm{MPN} / 100 \mathrm{~mL})$. In case of other microbial indicators like faecal coliform, faecal streptococci and E.coli the data showed significantly $(p<0.05)$ lower values for effluent in comparison to the raw sewage $(p<0.05)$. Average values of Faecal coliform, E. coli and Faecal streptococci concentrations in the inlet samples were found to be $7.83 \pm 0.07 \mathrm{MPN} / 100 \mathrm{~mL}$, $7.63 \pm 0.14 \mathrm{MPN} / 100 \mathrm{~mL}$ and $6.85 \pm 0.11 \mathrm{MPN} / 100 \mathrm{~mL}$ respectively. Similarly, FC, E. coli and FS concentrations were found to vary in the effluent samples (Table 1).

The comparison of Percentage efficiency rate showed significant differences among different microbial parameters. Removal efficiency rate was greater for Faecal coliform (72.33\%) and least in Faecal streptococci (38.7\%; Table 2).

The results show significant variation in different parameters of microbial load among different seasons $(p<0.05)$. The efficiency rate of total coliform is significantly higher in summer (54.85, Chi-square $=11.2, \mathrm{p}<0.05)$ and least in winter (48.15). Other microbial parameters also show significant variation among different seasons (Table 2 and Table 3). When mean values of microbial load (Faecal coliform, E. coli and Faecal streptococci) were compared by using box plot showed least mean values in winter in comparison to other seasons (Figure 1). 
Wani et al. Journal of Environmental Engineering \& Ecological Science 2013, http://www.hoajonline.com/journals/pdf/2050-1323-2-1.pdf

Table 2. Log concentration of influent and effluent log removal (\%) efficiency of microbial load on seasonal basis.

\begin{tabular}{|c|c|c|c|c|c|c|c|c|c|c|c|c|}
\hline \multirow[t]{2}{*}{ Season } & \multicolumn{3}{|c|}{ Total coliform } & \multicolumn{3}{|c|}{ Faecal coliform } & \multicolumn{3}{|c|}{ E. coli } & \multicolumn{3}{|c|}{ Faecal streptococci } \\
\hline & Raw & Effluent & $\begin{array}{l}\text { log removal } \\
(\%) \text { efficiency }\end{array}$ & Raw & Effluent & $\begin{array}{l}\text { log removal } \\
(\%) \text { efficiency }\end{array}$ & Raw & Effluent & $\begin{array}{l}\text { log removal } \\
(\%) \text { efficiency }\end{array}$ & Raw & Effluent & $\begin{array}{l}\text { log removal } \\
\text { (\%) efficiency }\end{array}$ \\
\hline Summer & 8.72 & 7.49 & $1.25(54.85)$ & 7.81 & 6.72 & $1.11(72.33)$ & 7.58 & 6.79 & $0.80(61.44)$ & 6.86 & 6.06 & $0.82(43.93)$ \\
\hline Autumn & 8.89 & 7.62 & $1.28(51.10)$ & 7.85 & 6.74 & $1.15(68.09)$ & 7.65 & 6.86 & $0.81(62.12)$ & 6.94 & 6.08 & $0.86(44.35)$ \\
\hline Winter & 8.62 & 7.73 & $0.92(48.15)$ & 7.74 & 6.86 & $0.90(56.94)$ & 7.48 & 6.85 & $0.63(51.44)$ & 6.70 & 6.04 & $0.66(38.70)$ \\
\hline Spring & 8.90 & 7.66 & $1.30(50.39)$ & 7.93 & 6.80 & $1.15(68.36)$ & 7.82 & 6.81 & $1.04(59.67)$ & 6.93 & 6.15 & $0.78(40.597)$ \\
\hline
\end{tabular}

Table 3. Seasonal variation in efficiency rate of microbial load in Hazratbal sewage treatment plant with Chi-Square test.

\begin{tabular}{lcc}
\hline Season & Chi square & P-value \\
\hline Summer & 11.2 & $\mathrm{P}<0.05$ \\
Autumn & 7.5 & $\mathrm{P}<0.05$ \\
Winter & 10.1 & $\mathrm{P}<0.05$ \\
Spring & 11.3 & $\mathrm{P}<0.05$ \\
\hline
\end{tabular}

\section{Discussion}

It is evident from the data that microbial load showed significant differences between the inlet and outlet, water samples nevertheless, these variations do not match as per Indian national standards. As per Indian standards, Total coliform, Faecal coliform and Faecal streptococci should be less than $10000 \mathrm{MPN} / 100 \mathrm{ml}, 2500 \mathrm{MPN} / 100 \mathrm{ml}$ $500 \mathrm{MPN} / 100 \mathrm{ml}$ respectively for discharge into some water body. The high coliform count in raw sewage obtained in our results may be an indication that the sewage is comprised of faecal matter coming from household latrines (APHA, 1998). The presence of pathogenic bacteria in treated wastewater effluent is a potential public health hazard, as this water source is directly discharged in receiving water bodies and may be used by communities for multiple purposes. At the inlet physico-chemical parameter values are relatively high which causes microbial biomass development in particular increase faecal coliform, faecal streptococci [10]. So, it is essential to include tertiary treatment step in STPs so that complete disinfection of effluent is done [11].

Efficiency rate showed significant differences between raw and effluent in all the microbial parameters. Hazratbal sewage treatment plant uses FAB based technology which is a recent technique for the removal of pollutants from municipal sewage. The comparatively low efficiency rate in this sewage treatment plant may be because of the fact that primary sedimentation is not carried out in this sewage treatment plant and as such efficiency rate is affected [12]. The reduction of microbes also depends on protozoan predation, settlement of suspended solids, inactivation due to sunlight, activity of bacteria and environmental conditions [13]. It is clear from our results that large amount of microbial load is retained even after the purification process [14,15 and 16]. However, it is to be mentioned that these investigated STPs were using different types of technologies including Activated Sludge
Process (ASP), Extended Aeration (EA), BIOFORE, Trickling filter and Oxidation Pond for the treatment of sewage [16].

Seasons seem to play an important role in predicting the removal efficiency of this STP. The greater efficiency rate in summer and autumn season could be due to the efficient working capability of mechanical parts during these months. Moreover feasible temperature in these months brings about the inactivation of microbes. The reverse is the case in winter months when harsh climatic conditions may reduce the efficiency of machine parts and thus will reduce efficiency rate. So it can be concluded that temperature plays an important role in working capability of Hazratbal wastewater treatment plant. According to Central Pollution Control Board (2008 report), the effluent concentration of Total coliforms was observed lower in winters whereas the highest effluent TC concentration was noted during monsoon period [17]. In case faecal coliforms, higher effluent concentration was during summer and monsoon period and lowest in winters whileas almost similar FC removal was reported during all the seasons. These findings coincide with our results.

\section{Conclusion}

From the study it was concluded that efficiency rate of Hazratbal sewage treatment plant did not reach to the level of standards and international standards and as such discharge of effluent from this sewage treatment plant into the lake is not suitable prior to complete disinfection. It is further recommended that authorities should include tertiary treatment processes such as rapid sand filtration, UV disinfection, artificial lagoons, wetlands, adequate contact time etc. to increase the removal efficiency of this STP. It is also recommended that wastewater effluents should be routinely monitored to ensure that strict adherence to effluent discharge standards is met.

\section{Competing interests}

The authors declare that they have no competing interests.

\section{Acknowledgement}

We are greatly indebted to LAWDA (Lakes and Waterbody Development Authority) for their cordial help during my period of work.

\section{Publication history}

Received: 29-Nov-2012 Revised: 08-Jan-2013

Accepted: 15-Jan-2013 Published: 28-Jan-2013 


\section{References}

1. Usha P. Raghupathi et al. : Status of Water Supply, Sanitation and Solid Waste Management in Urban Areas. Central Public Health and Environmental Engineering Organisation (CPHEEO) Ministry of Urban Development Government of India, 2005

2. Akpor $O B$ and Muchie $M$ : Environmental and public health implications of wastewater quality. African Journal of Biotechnology. 2011, 10:2379-2387. | PDF

3. Geldreich, EE: Water and Sewage Works Ref. No. R-98.1967

4. Momba, MNB, Mfenyana, C: Inadequate treatment of wastewater: A source of coliform bacteria in receiving surface water bodies in developing countries- Case Study: Eastern Cape Province of South Africa. In: Water Encyclopedia- Domestic, Municipal and Industrial Water Supply and Waste Disposal. Lehr JH, Keeley J (eds). John Wiley \& Sons Inc. 2005, pp. 661-667. | Article

5. Paillard D, Dubois V, Thiebaut R, Nathier F, Hoogland E, Caumette P and Quentin C: Occurrence of Listeria spp. in effluents of French urban wastewater treatment plants. Appl Environ Microbiol 2005, 71:75626. | Article | PubMed Abstract | PubMed Full Text

6. Hurst CJ, Knudsen GR, Mclnerney MJ, Stetzenbach LD and Walter MV (eds): Manual of Environmental Microbiology. ASM Press, Washington DC. 1997

7. Americal Public Health Association (APHA): Standard Methods for the Examination of Water and Waste water, 19th ed. American Water works Association and Water Pollution Control Federation Publication, Washington, D.C. 1998.

8. Kantachote $D$, Kantasorn, $D$ and Cherdchan S: Treatment fficiency in wastewater treatment plant of Hat Yai Municipality by quantitative removal of microbial indicators. Songklanakarin J. Sci. Technol. 2009, 31:567-576. | PDF

9. Shalaby IMI, Altalhy AD and Mosallam HA: Preliminary field study of a model plant for sewage water treatment using Gravel Bed Hydroponics Method. World Applied Sci. J. 2008, 4: 238-243. | Article

10. Rajeb $A B$, Kallali $H$, Saidi $N$, Abidi $S$, Jedidi $N$ and Hassen $A$ : Physicochemical and Microbial Caracteristics Performency in Wastewater Treated Under Aerobic Reactor. American Journal of Environmental Sciences. 2011, 7: 254-262. | Article

11. Koivunen J, Siitonen A and Heinonen-Tanski H: Elimination of enteric bacteria in biological-chemical wastewater treatment and tertiary filtration units. Water Res 2003, 37:690-8. | Article | PubMed

12. EPA. Washington, DC: "Primer for Municipal Waste water Treatment Systems." Document no. EPA 832-R-04-001. 2004

13. Katsoyiannis A and Samara C: Persistent organic pollutants (POPs) in the sewage treatment plant of Thessaloniki, northern Greece: occurrence and removal. Water Res 2004, 38:2685-98. | Article | PubMed

14. Cohen J and Shuval HI: Coliforms, faecal coliforms and faecal streptococci as indicators of water pollution. Water, Air and Soil Pollution, 1972, 2:85-95. | Article

15. Payment P, Plante R and Cejka P: Removal of indicator bacteria, human enteric viruses, Giardia cysts, and Cryptosporidium oocysts at a large wastewater primary treatment facility. Can J Microbiol 2001, 47:188-93. | Article | PubMed

16. Jamwal P, Jamwal P, Mittal A K and Mouchel J M: Efficiency evaluation of sewage treatment plants with different technologies in Delhi (India). Environ Monit Assess 2009, 153:293-305. | Article | PubMed

17. Central Pollution Control Board: Status of water quality in india- 2007. Ministry of Environment and Forests. 2008.

\section{Citation:}

Wani D, Pandit AK and Kamili AN: Microbial assessment and effect of seasonal change on the removal efficiency of FAB based sewage treatment plant. journal of Environmental Engineering and Ecological Science 2013, 2:1. http://dx.doi.org/10.7243/2050-1323-2-1 